\title{
In Vitro Study: Effect of Cobalt(II) Chloride Against Dengue Virus Type 1 in Vero Cells
}

\author{
Yovilianda Maulitiva Untoro', Teguh Hari Sucipto ${ }^{2 *}$, Harsasi Setyawati ${ }^{1}$, Anisa Maharani ${ }^{1}$, Novia \\ Faridatus Sholihah ${ }^{1}$, Siti Churrotin ${ }^{2}$, Ilham Harlan Amarullah ${ }^{2}$ and Soegeng Soegijanto ${ }^{2}$
}

1. Department of Chemistry, Faculty of Science and Technology, Universitas Airlangga, Campus C, Surabaya Indonesia 60115

2. Dengue Study Group, Institute of Tropical Disease, Universitas Airlangga, Surabaya Indonesia 60115

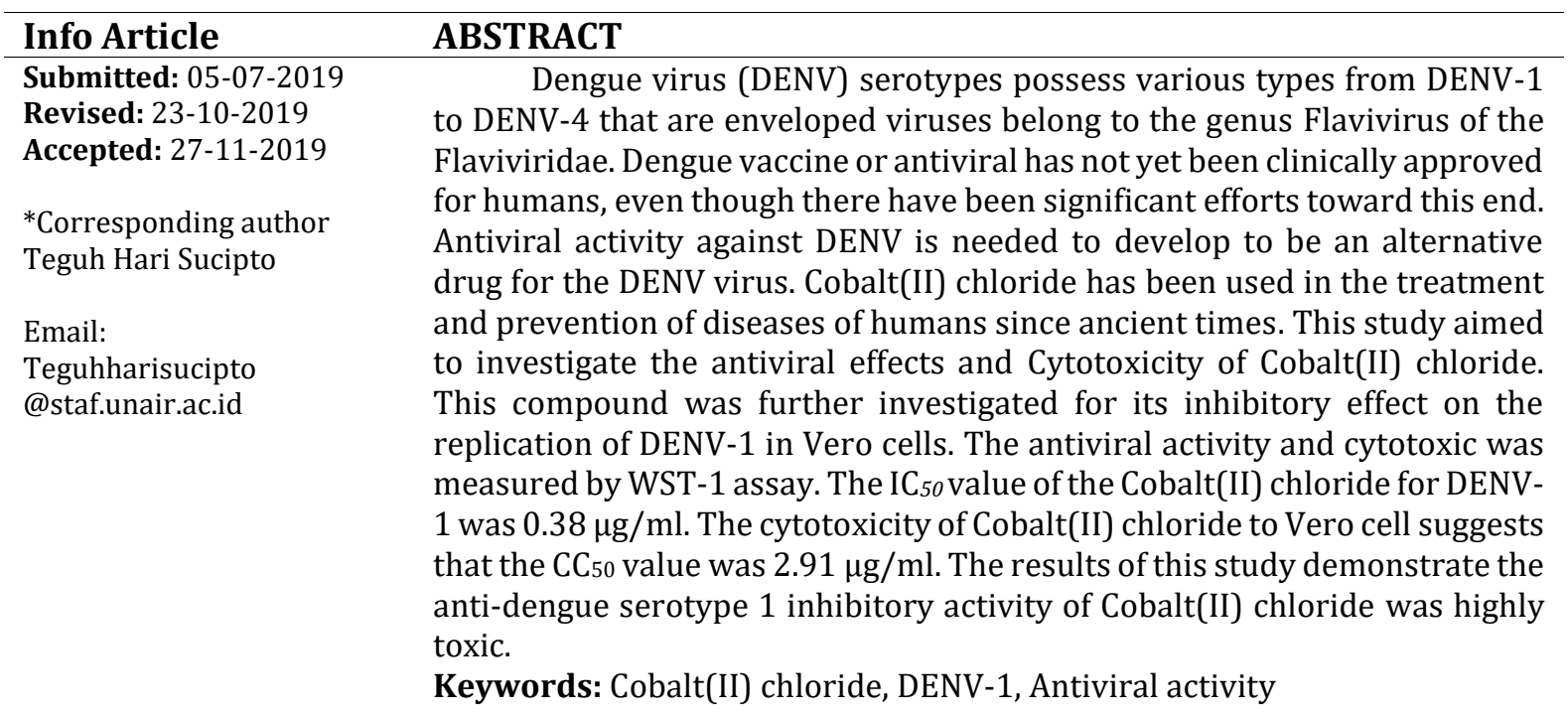

\section{INTRODUCTION}

Dengue virus (DENV) is a positive-sense RNA virus replicating in the membranous compartments of cytoplasm. Viral infection induces the dengue virus with significant human viral pathogens transmitted by Aedes aegypti. Moreover, about 50 million infections occur each year, and over 2.5 billion people at risk (Gubler, 2002). There are four serotypes of the dengue virus. Four serotypes of dengue virus: DENV-1, DENV-2, DENV3 , and DENV-4) are transmitted by the vector mosquitoes such as Aedes aegypti and Aedes albopictus (Halstead, 2015). Vaccines have been developed for DENV infection (Woodland, 2015). Recently, WHO immunization group (Strategic Advisory Group of Experts; SAGE) has recommended the use of partially effective dengue vaccine (a live attenuated tetravalent dengue vaccine developed by Sanofi Pasteur; CYD-TDV, named Dengvaxia) that has been licensed and used in 11 countries including Brazil, Mexico, Singapore, Thailand and Indonesia (Aguiar et al., 2016). Nevertheless, control of the dengue virus through the use of vaccination has proved to be elusive
(Burke et al., 2001). A new approach to controlling DENV infection is needed. Antiviral activity of DENV is required to develop an alternative drug for the dengue virus. The reason caused by the alternative drug is not an effective antiviral treatment for DENV, and the patient is not supportively-treated with any specific treatment measures (Zandi et al., 2011).

Cobalt(II) chloride is an inorganic compound of cobalt and chlorine, with the formula $\mathrm{CoCl}_{2}$. It is usually supplied as the hexahydrate $\mathrm{CoCl}_{2} \cdot 6 \mathrm{H}_{2} \mathrm{O}$, which is one of the most commonly used cobalt compounds in the laboratory (Greenwood et al., 1997). Cobalt is mainly found in the corrin ring of vitamin B12 (also known as cobalamin) and also supports metabolic and red blood processes (Chang et al., 2010). Cobalt(II) chloride has been used in the treatment and prevention of diseases of humans since ancient times. It has been known for 45 years that small doses of cobalt produce polycythemia in many types of animals, including humans (Devlin et al., 1967). In 1976, Duckham was investigated about the treatment of refractory anemia of chronic renal 
failure with cobalt chloride. The research has shown that cobalt is a useful addition to the available therapy in the management of the refractory anemia of chronic renal failure (Duckham et al., 1975). Enteric-coated cobalt chloride $25 \mathrm{mg}$ twice daily is recommended for 12 weeks. The anemia will respond in the majority of patients during this time. It appears that within this period of treatment, the serum cobalt levels will reach a peak and level off. They suggest that either the maintenance dose of cobalt chloride is reduced to $25 \mathrm{mg}$ daily or that courses of three months be given intermittently.

In a previous study, Dutta et al. investigated the coordination of different ligands to copper (II), and cobalt(III) metal centers enhance the Zika virus and dengue virus loads in both arthropod cells and human keratinocytes (Dutta et al., 2017). These findings suggest that the use of $\mathrm{Cu}$ (II) or $\mathrm{Co}$ (III) conjugation to organic compounds, in insect repellents and/or food additives could enhance DENV-2/ZIKV loads in human cells and perhaps induce pathogenesis in infected individuals or individuals pre-exposed to such conjugated complexes. However, there are just published data about anti-DENV type 2 activities of cobalt compounds. Therefore, the research aimed to determine the antiviral activity of Cobalt(II) chloride against dengue virus type 1 and the cytotoxicity of Cobalt(II) chloride to Vero cell.

\section{MATERIALS AND METHODS}

The chemical reagents used in this research were the Cobalt(II)-chloride (Sigma-Aldrich, Germany), dimethyl sulfoxide (Merck 99.98\%, Germany), Minimum Essential Eagle Medium (Sigma-Aldrich, Germany), Dengue virus serotype 1 Surabaya Isolate (AB915377), Methanol (Merck 99.98\%, Germany), Vero cell (African green monkey kidney), Viral ToxGlo Assay (Promega, USA), and Cell Proliferation Reagent WST-1 (Roche Applied Science).

\section{Antiviral activity assay}

Vero Cells with concentration $1 \times 10^{6} \mathrm{sel} / 10$ $\mathrm{mL}$ were seeded into a 96 well plate and incubated plates containing cells at $37^{\circ} \mathrm{C}$ in a humidified $\mathrm{CO}_{2}$ incubator for at least $4 \mathrm{~h}$ (and up to $24 \mathrm{~h}$ ) to facilitate attachment and allow cells to recover from seeding stresses. One hundred microliters of Dengue virus with concentration $4 \times 10^{5} \mathrm{FFU} / \mathrm{mL}$ stock were combined with various concentrations of $\mathrm{CoCl}_{2}$. The concentrations of $\mathrm{CoCl}_{2}$ used in this study are $50 \mu \mathrm{g} / \mathrm{mL} 25 \mu \mathrm{g} / \mathrm{mL}, 12.5 \mu \mathrm{g} / \mathrm{mL}$, $6.25 \mu \mathrm{g} / \mathrm{mL}, 3.13 \mu \mathrm{g} / \mathrm{mL}, 1.56 \mu \mathrm{g} / \mathrm{mL}$ (Zandi, 2011). After one hour of exposure to the dengue virus at room temperature, $100 \mu \mathrm{L}$ of the $\mathrm{CoCl}_{2}$ treated virus was added to Vero cells in individual wells. Cells were infected for $24 \mathrm{~h}$. The unabsorbed virus was removed and replaced with MEM. Twenty-four hours post-infection $100 \mu \mathrm{L}$ of Viral ToxGlo. $100 \mu \mathrm{L}$ of ATP Detection Reagent was added to each well of a 96 -well plate $(25 \mu \mathrm{L}$ to each well of a 384 -well plate) and wait at least $10 \mathrm{~min}$ before measuring luminescence. Calculate $\mathrm{IC}_{50}$ values by plotting net RLU values (subtracting the average of blank wells) versus compound concentration. The $\mathrm{IC}_{50}$ value is the compound concentration that produced a $50 \%$ increase in ATP levels compared to virus and novirus controls.

\section{In vitro cytotoxicity assay}

Cytotoxicity used WST-1 cell proliferation reagent by Roche Applied Science, Mannheim, Germany. The assay is very sensitive: it can detect 1,000 cells/well of a 96 -well plate reader. Vero cells $\left(1 \times 10^{5}\right.$ cells $\left./ \mathrm{mL}\right), \quad 500 \mu \mathrm{L}$ of serial dilution compound, and a total of $10 \mu \mathrm{L}$ of Cell Proliferation Reagent was added to each well of a 96-well plate and incubated under $5 \% \mathrm{CO}_{2}$ at $37^{\circ} \mathrm{C}$ for $1 \mathrm{~h}$. The various concentration of $\mathrm{CoCl}_{2}$ are $50 \mu \mathrm{g} / \mathrm{mL}$ $25 \mu \mathrm{g} / \mathrm{mL}, \quad 12.5 \mu \mathrm{g} / \mathrm{mL}, \quad 6.25 \mu \mathrm{g} / \mathrm{mL}, \quad 3.13 \mu \mathrm{g} / \mathrm{mL}$, $1.56 \mu \mathrm{g} / \mathrm{mL}$ (Zandi, 2011). The plate was read at 450nm (main filter) and $655 \mathrm{~nm}$ (reference filter) using an iMarkTM Microplate Absorbance Reader.

\section{RESULT AND DISCUSSION Antiviral activity}

Antiviral activity is a homogeneous, addmix-measure method intended that used in research studies to identify cytopathic effect (CPE) induced by a viral infection. Viral ToxGlo assay a more accurate quantitative measure of viral inhibition. Cells were either incubated with MEM, infected with dengue virus, or infected with $\mathrm{CoCl}_{2}$ treated dengue virus. A significant inhibitory activity to that of the complex Cobalt (II) chloride was displayed against the tested pathogenic DENV1 in Vero cells. In the inhibitory activity test, we studied the ability of the compound to produce a direct virus-inactivating effect. The basis of this test is the measurement of the ability of living cells based on mitochondrial activity from cell culture. This method is based on the ATP generated by active cells on a live-cell. Microplate reader calculated the live-cell after incubation for $24 \mathrm{~h}$. 
The percentage inhibition of the development of dengue virus type- 1 by the test sample of Co (II) chloride are presented on the figure (Figure 1).

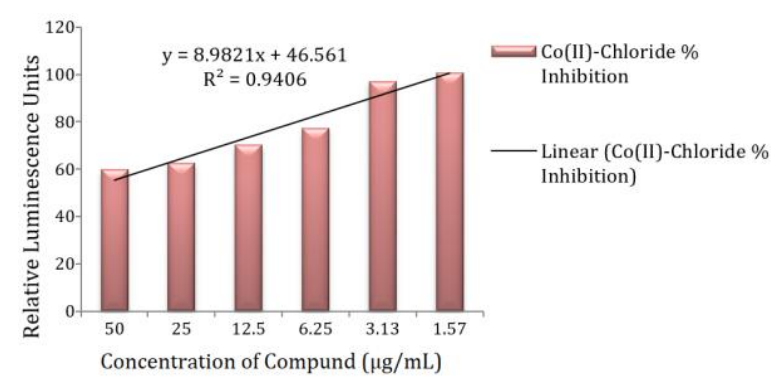

Figure 1. Inactivation of DENV-1 at variation concentrations of Cobalt(II) chloride

The mechanism analogy of inhibition DENV2 from the previous study, it is also possible that an intact compound can diffuse across the cell membrane or virus capsid, or that $\mathrm{Co}(\mathrm{II})$ solute can enter cells through the transport and ion/voltagegated channels. While Co(II) themselves can interact with oxidative organelles or redox-active protein to induce reactive oxygen species (ROS) in cells, Co(II) produced can also induce ROS by various chemical reactions, and ROS can break DNA strands and alter gene expression. Another possible mechanism is that Co(II) can chelate with biomolecules or dislodge the metal ions in some metalloproteins, leading to dysfunctional proteins and further cell inactivation (Broglie et al., 2015).

The $\mathrm{IC}_{50}$ value was determined from the concentration-response curve (Figure 1); the $\mathrm{IC}_{50}$ value was $0.38 \mu \mathrm{g} / \mathrm{mL}, R^{2}$ was 0.9406 . Based on the value of the $\mathrm{IC}_{50}$ Cobalt(II)-Chloride was a highly toxic compound. The antiviral activity of Cobalt has been described for distinct viruses. Delehanty et al. (2008) investigated the antiviral activity of Co(III)hexammine to Sindbis virus replication. Co(III)hexammine, significantly inhibited Sindbis virus replication in baby hamster kidney (BHK) cells in a dose and time-dependent manner. In plaque assays, the incubation of Co(III)-hexammine with Sindbis virus resulted in a dose-dependent decrease in virus replication when measured at both 24 and $48 \mathrm{~h}$ post-infection Over the concentration range of $0-5 \mathrm{mM} \mathrm{Co}(\mathrm{III})$-hexammine, the $\mathrm{IC}_{50}$ for the inhibition of viral replication was determined to be $0.10 \pm 0.04 \mathrm{mM}$ at $48 \mathrm{~h}$. Analysis by flow cytometry confirmed that $\mathrm{Co}$ (III) hexammine mediated a concomitant dose-dependent increase in BHK cell viability and a decrease in the percentage of Sindbis virus-infected cells
$\left(\mathrm{IC}_{50}=0.13 \pm 0.04 \mathrm{mM}\right)$. These research findings demonstrate for the first time that $\mathrm{Co}(\mathrm{III})$ hexammine possesses potent antiviral activity (Delehanty et al., 2008).

In the previous study, the majority of the inorganic ions tested enhanced the anti-herpes simplex virus type 1 (HSV-1) activity, $\mathrm{EC}_{50}$ (effective concentration) of $\mathrm{ZnCl}_{2}, \mathrm{CuCl}_{2}$, and $\mathrm{FeCl}_{3}$ were $1.430 \mu \mathrm{M}, 121 \mu \mathrm{M}$, and $35.8 \mu \mathrm{M}$. All cations tested showed higher antiviral activity except for zinc. The mechanism of action was not determined during study, but evidence suggests that these chelates may target the extracellular attachment between the virion glycoprotein $B$ and the heparin sulfate proteoglycans on the cells' surface (Langland et al., 2018). The result of Co(III) complexes containing $\mathrm{N}, \mathrm{O}$ donor ligands activity for HSV-1 has inhibited replication virus with as little as $5 \mu \mathrm{g} / \mathrm{mL}$ required for active antiviral (Chang et al., 2010). Many different metal ions are required to support the metabolism of cells. The suggestion has been made that all nucleotidyl transferases are metalloenzymes, and the involvement of zinc ions in both DNA and RNA polymerases is well documented. The attachment of a copper complex to an mRNA that is synthesized late in the infective cycle of viruses would affect the function of the mRNA, and this may account for the antiviral activity of these compounds (Hutchinson, 1985).

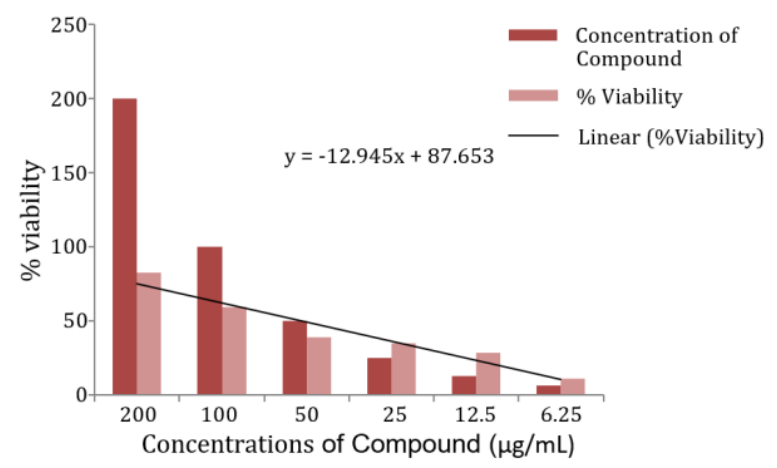

Figure 2 Cytotoxicity of Cobalt (II) chloride for Vero Cells at variation concentrations

\section{Cytotoxicity of Cobalt(II) chloride to Vero Cell}

Cobalt (II) chloride was screened for its cytotoxicity against Vero cells at different concentrations to determine the $\mathrm{CC}_{50}$ by WST- 1 assay. The $\mathrm{CC}_{50}$ value was found to increase with an increasing concentration of the test compound (Figure 2). The $\mathrm{CC}_{50}$ of Cobalt (II) chloride for Vero cells was $2.91 \mu \mathrm{g} / \mathrm{mL}$. In this study, we have examined the relationship between the 
concentration of Vero cells in the culture medium and the cytotoxic potency of Cobalt(II)-chloride.

In the previous study, Sucipto et al. investigated the antiviral activity of Copper(II) chloride dehydrate against dengue virus type-2 in Vero cell. It has been revealed that Co(II) is more toxic than $\mathrm{Cu}(\mathrm{II})$ with a $\mathrm{CC}_{50}$ value of $5.03 \mu \mathrm{g} / \mathrm{mL}$ (Sucipto et al., 2017). Copper(II) was non-toxic to human erythrocyte cells even at a concentration of $500 \mu \mathrm{g} / \mathrm{mL}$ (Lv et al., 2006). The effects of metal solutions containing $\mathrm{Al}(\mathrm{III}), \mathrm{Cd}(\mathrm{II}), \mathrm{Hg}(\mathrm{II})$, and $\mathrm{Pb}$ (II) to Vero cells were $6.25,0.83,3.7,2.9$, and $3.4 \mu \mathrm{g} / \mathrm{mL}$ respectively (Traoré et al., 1999). The $\mathrm{CoCl}_{2} .6 \mathrm{H}_{2} \mathrm{O}$ being the most effective antiproliferative agent, hence it was further tested against cancer cells and induced maximum cell death in IMR-32 followed by PC-3 and A549 with values of 7.12, 21.91, and $29.81 \mu \mathrm{g} / \mathrm{mL}$ respectively (Mahey et al., 2016). Thus, apoptosis was found to execute in cells by over generation of ROS (reactive oxygen species) and concomitant damage to the mitochondrial membrane.

For Vero cells incubated with polyoxometalate-stabilized gold nanoparticles for $24 \mathrm{~h}$ was from $20-100 \mu \mathrm{g} / \mathrm{mL}$, approximately 93$95 \%$ was shown to be alive, $0.1-0.3 \%$ apoptotic. This data is commensurate with little or no toxicity when compared to the control sample (Gabas et al., 2016). The synthesis of metal silver nanoparticles effect to Vero cell lines was found to be $18.15 \mu \mathrm{g} / \mathrm{mL}$. The cytotoxic effects had indicated the occurrence of active physicochemical interaction of silver atoms with the functional groups of intracellular proteins, as well as with the nitrogen bases and phosphate groups in DNA (Prasannaraj et al., 2017).

\section{CONCLUSION}

Cobalt(II) chloride was shown to have antiviral activity against DENV-1, a member of the Flavivirus genus, in vitro. Antiviral activity results suggest that the $\mathrm{IC}_{50}$ value was $0.38 \mu \mathrm{g} / \mathrm{ml}$. Cytotoxicity of Cobalt(II) chloride to Vero cell suggests that the $\mathrm{CC}_{50}$ value was $2.91 \mu \mathrm{g} / \mathrm{ml}$. Based on the value of the $\mathrm{IC}_{50}$ and $\mathrm{CC}_{50}$ value, Cobalt(II) chloride was a highly toxic compound.

\section{ACKNOWLEDGMENTS}

This study was funded by the Student Creativity Program (Program Kreativitas Mahasiswa, PKM) grant from the Ministry of Research, Technology, and Higher Education of the Republic of Indonesia and Mandatory Research Grant (Hibah Riset Mandat) of Universitas
Airlangga 2019. The authors thank the Institute of Tropical Disease Universitas Airlangga for a research internship opportunity in the Dengue Laboratory; Japan Initiative for Global Research Network on Infectious Disease (J-GRID); and for the Center of Excellence (COE) program by the Ministry of Research, Technology, and Higher Education of the Republic of Indonesia.

\section{REFERENCES}

Aguiar M., Stollenwerk N., Halstead SB., 2016. The impact of the newly licensed dengue vaccine in endemic countries. PLoSNegl. Trop. Dis. 10: 1-23.

Broglie JJ., Alston B., Yang C., Ma L., Adcock AF., Chen W., Yang L., 2015. Antiviral activity of gold/copper sulfide core/shell nanoparticles against human norovirus virus-like particles. PloS ONE. 10: 1-14

Burke DS., Monath TP., 2001. Flaviviruses. DM. Knipe, PM. Howley (Eds), FieldsVirology (4 ${ }^{\text {th }}$ Edition), Lippincott Williams \& Wilkins, Philadelphia. pp. 852-921.

Chang EL., Simmers C., Knight DA., 2010. Cobalt Complexes as Antiviral and Antibacterial Agents. Pharmaceuticals. 3: 1711-1728.

Delehanty JB., Bongard JE., Thach DC., Knight DA., Hickey TE., Chang EL., 2008. Antiviral properties of cobalt(III)-complexes. Bioorg. Med. Chem. 16: 830-837.

Devlin JG., Brien T., Stephenson N., 1967. Case of Cobalt Poisoning. Brit. Med. J. 1: 544-545

Duckham JM., Lee HA., 1976. The Treatment of Refractory Anaemia of Chronic Renal Failure with Cobalt Chloride. Q. J. Med. 178: 277294.

Dutta S., Celestine MJ., Khanal S., Huddleston A., Simms C., Arca JF., Mitra A., Heller L., Kraj PJ., Ledizet M., Anderson JF., Neelakanta G., Holder AA., Sultana H., 2018. Coordination of different ligands to copper(II) and cobalt(III) metal centers enhances Zika virus and dengue virus loads in both arthropod cells and human keratinocytes. Biochim. Biophys. Acta Gen. Subj. 1862: 40-50

Gabas IM., Stepien G., Moros M., Mitchell SG., de la Fuente JM., 2016. In vitro cell cytotoxicity profile and morphological response to polyoxometalate-stabilised gold nanoparticles. New J. Chem. 40: 1039-1047

Greenwood NN., and A. Earnshaw. 1997. Cobalt, Rhodium and Iridium, in Chemistry of the Elements. Butterworth-Heinemann, Oxford, England. pp. 1113-1143. 
Gubler DJ., 2002. Epidemic dengue/dengue hemorrhagic fever as a publichealth, social and economic problem in the 21st century. Trends. Microbiol. 10: 100-103.

Halstead SB., 2008. Dengue Virus-mosquito Interactions. Annu. Rev. Entomol. 53: 273291.

Hutchinson DW., 1985. Metal chelators as potential antiviral agents. Antiviral Res. 5: 193-205

Langland J., Jacobs B., Wagner C., Ruiz G., Cahill TM., 2018. Antiviral activity of metal chelates of caffeic acid and similar compounds towards herpes simplex, VSV-Ebola pseudotyped and vaccinia viruses. Antiviral Res. 160: 143150

Lv J., Liu T., Cai S., Wang X., Liu L., Wang Y., 2006. Synthesis, structure and biological activity of cobalt(II) and copper(II) complexes of valine-derived schiff bases. J. Inorg. Biochem. 100: 1888-1896.

Mahey S., Kumar R., Arora R., Mahajan J., Arora S., Bhardwaj R., Thukal AK., 2016. Effect of cobalt(II) chloride hexahydrate on some human cancer cell lines. Springer Plus. 5:114

Prasannaraj G., Venkatachalam P., 2017. Green engineering of biomolecule-coated metallic silver nanoparticles and their potential cytotoxic activity against cancer cell lines. Adv. Nat. Sci.: Nanosci. Nanotechnol. 8: 1-11

Sucipto TH., Churrotin S., Setyawati H., Kotaki T., Martak F., Soegijanto S., 2017. Antiviral Activity of Copper(Ii)Chloride Dihydrate Against Dengue Virus type-2 In Vero Cell. Indonesian J. Trop. Infect. Dis. 6: 84-87

Traoré A., Bonini M., Dano SD., Creppy EE., 1999. Synergistic effects of some metals contaminating mussels on the cytotoxicity of the marine toxin okadaic acid. Arch. Toxicol. 73: $289-295$

Woodland DL., 2015. Vaccines Against Dengue Virus. Viral Immunol. 28: 75.

Zandi K., Teoh BT., Sam SS., Wong PF., Mustafa MR., Abubakar S., 2011. Antiviral Activity of Four Types of Bioflavonoid Against Dengue Virus Type-2. Virol. J. 8: 1-11. 